\title{
2 High efficiency and selectivity of MgFe-LDH modified wheat-straw biochar in the removal
}

3 of nitrate from aqueous solutions

4

5 Lihong Xue ${ }^{\mathrm{a}, \mathrm{b}}$, Bin Gao $^{\mathrm{b}^{*}}$, Yongshan Wan ${ }^{\mathrm{c}}$, June Fang ${ }^{\mathrm{b}}$, Shengsen Wang ${ }^{\mathrm{b}}$, Yuncong $\mathrm{Li}^{\mathrm{c}}$, Rafael

6 Muñoz-Carpena ${ }^{\mathrm{b}}$, Linzhang Yang $^{\mathrm{a}}$

7

8

$9 \quad{ }^{a}$ Jiangsu Academy of Agricultural Sciences, Nanjing, 210000, China

$10{ }^{b}$ Department of Agricultural and Biological Engineering, University of Florida, Gainesville, FL

11 32611, United States

$12{ }^{c}$ Department of Soil and Water Science, University of Florida, Gainesville, FL 32611, United

\section{States}

14

15

16

17 * Corresponding author. Tel.: (352) 392-1864x285; fax: (352) 392-4092. Email address:

18 bg55@ufl.edu.

19 


\section{Abstract:}

$21 \quad \mathrm{Mg}-\mathrm{Fe}$ layered double hydroxide $(\mathrm{MgFe}-\mathrm{LDH})$ particles were incorporated into wheat-straw

22 biochar by liquid-phase deposition. The obtained biochar/MgFe-LDH composite was used to

23 remove nitrate from aqueous solutions. X-ray diffraction patterns demonstrated that LDH

24 particles were successfully deposited onto the carbon surface within the biochar matrix.

25 Adsorption kinetic and isotherm studies and the effects of co-existing anions and adsorbents

26 dosages were investigated using laboratory batch sorption experiments. The biochar/MgFe-LDH

27 composite showed a strong sorption ability to nitrate in aqueous solutions with the Langmuir

28 maximum adsorption capacity of $24.8 \mathrm{mg} / \mathrm{g}$. A high selectivity for nitrate of the

29 biochar/MgFe-LDH composite was also observed irrespective of the co-existence of sulfate and

30 phosphate. The biochar/MgFe-LDH composite can thus be potentially used as an alternative

31 adsorbent for the treatment of nitrate-contaminated waters as well as a soil amendment for the

32 reduction of soil nitrate leaching.

34 Keywords: engineered biochar; layered double hydroxides; nitrate adsorption; ion selectivity 


\section{Introduction}

38 Excess levels of nitrate in water have become a serious concern worldwide. Nitrate

39 contamination from both point and non-point sources include agricultural and urban runoff,

40 disposal of untreated sanitary and industrial wastes in unsafe manners, leakages in septic systems,

41 landfill leachates, and animal manure. Due to its high water solubility and low adsorption affinity

42 to soils, nitrate is perhaps the most widespread groundwater contaminant in the world, posing a

43 serious threat to drinking water supplies [1]. High concentrations of nitrate in drinking water

44 may cause methemoglobinaemia, or blue baby syndrome, which has been cited as a risk factor in

45 developing gastric and intestinal cancer. The maximum contamination level set by the US

46 Environmental Protection Agency (EPA) for drinking water is $10 \mathrm{mg} / \mathrm{L}$ of $\mathrm{NO}_{3}-\mathrm{N}$, while the

47 guideline value of the World Health Organization (WHO) for drinking water is $50 \mathrm{mg} \mathrm{NO}_{3}{ }^{-} / \mathrm{L}$

48 Numerous techniques for the removal of nitrate from water and wastewater have been

49 reported [2]. These techniques can remove nitrate from water with varying levels of efficiency,

50 cost, and ease of operation. Adsorption is generally considered an effective water treatment

51 technique because of its convenience, ease of operation, and simplicity of design [2]. The

52 adsorption process can remove/reduce different types of organic and inorganic pollutants from

53 water or wastewater. Efficiency of nitrate removal from aqueous solutions by adsorption depends

54 largely on the adsorbent used [3].

55 Biochar, a renewable, low cost, and sustainable adsorbent, has received extensive attention

56 for the removal of contaminants from water and wastewater, including nitrate [4]. Mizuta et al. 
57 [5] found that bamboo powder charcoal can adsorb more nitrate than commercial activated

58 carbon and thus can serve as an attractive option for in situ treatment of nitrate-contaminated

59 groundwater and surface water. Several studies [6-9] have reported that porous $\mathrm{MgO}$-biochar

60 nanocomposites have high nitrate adsorption capacities. Furthermore, spent biochar loaded with

61 ammonium, nitrate, and phosphate can potentially be used as a slow-release fertilizer to enhance

62 soil fertility and sequester soil carbon.

63 Layered double hydroxide (LDH), known as one of the most promising inorganic

64 anion-exchangeable materials used for removing toxic anions from polluted water, has lately

65 been studied for the removal of nitrate [10-12]. Research showed that varying the metal

66 composition of $\mathrm{LDH}$ can change the anion selectivity, with Ni/Fe-LDH and $\mathrm{Mg} / \mathrm{Fe}-\mathrm{LDH}$ being

67 reported to have a relatively high selectivity for nitrate ions $[11,13]$. Use of LDHs as a slow

68 release fertilizer or anionic exchanger has also been proposed for increasing the nitrogen use

69 efficiency as well as nitrate buffering capacity of soils [14]. However, granular/bulk LDHs may

70 have limited sorption ability to anion contaminants due to the very tight stacking of layers [15].

71 Composite materials with colloidal and/or nanosized LDHs have thus been developed to

72 maximize the sorption ability of LDHs to various aqueous contaminants [16, 17]. However,

73 research on combining biochar with colloidal and/or nanosized LDHs was limited in the

74 literature with the exception of Zhang et al [7, 18], who reported that biochar/MgAl-LDH

75 ultrafine composite can be successfully obtained by liquid-phase deposition or hydrothermal

76 self-assembly for enhanced uptake capacity of phosphate. To the best of the authors' knowledge, 
77 none of previous studies have examined the sorption ability of LDH-biochar composites to

78 nitrate in aqueous solutions. Although various engineered methods have been developed to

79 modified biochars for contaminants removal $[19,20]$, only few studies have examined that

80 sorption of nitrate onto biochars [21, 22]. It is therefore crucial to develop novel biochar-based

81 sorbents that can effectively remove nitrate from aqueous solutions.

82 The overarching objective of this study was to evaluate the potential application of

83 biochar-LDH composite in the removal of nitrate from aqueous solutions. Biochar was derived

84 from wheat straw through slow pyrolysis and then modified with MgFe-LDH through

85 liquid-phase deposition. A range of laboratory experiments were then conducted to characterize

86 the physicochemical properties and sorptive ability of the MgFe-LDH modified biochar to nitrate

87 under various conditions. The specific objectives were as follows: (1) synthesize and

88 characterize biochar/MgFe-LDHs composite; (2) study the nitrate adsorption characteristics of

89 the composite; and (3) evaluate the efficiency and selectivity of the composite in the removal of

90 nitrate ions.

91

\section{2. Materials and methods}

93 2.1. Materials

94 Analytical grade magnesium chloride hexahydrate $\left(\mathrm{MgCl}_{2} \cdot 6 \mathrm{H} 2 \mathrm{O}\right)$, iron(III) chloride

95 hexahydrate $\left(\mathrm{FeCl}_{3} \cdot 6 \mathrm{H} 2 \mathrm{O}\right)$, potassium hydroxide $(\mathrm{KOH})$, potassium nitrate $\left(\mathrm{KNO}_{3}\right)$, and

96 potassium sulfate $\left(\mathrm{K}_{2} \mathrm{SO}_{4}\right)$ were purchased from Fisher Scientific and used as received. All 
97 experimental solutions were prepared using deionized (DI) water (18.2 MX) (Nanopure water,

98 Barnstead), which was also used to rinse and clean the samples. Wheat straw (WS) obtained

99 locally in Gainesville, FL was used as the biomass feedstock for biochar production. It was dried 100 and milled into small pieces $(2 \mathrm{~mm})$ before use.

\subsection{Preparation of samples}

Biochars were produced from the WS feedstock through slow pyrolysis at $600{ }^{\circ} \mathrm{C}$ for $1 \mathrm{~h}$ under $\mathrm{N}_{2}$ flow conditions following the procedure outlined in previous studies [23, 24].

MgFe-LDH deposited biochar composite was synthesized by the liquid-phase deposition method according to Zhang et al. [7]. Briefly, the $\mathrm{pH}$ of $100 \mathrm{~mL}$ aqueous solution containing $\mathrm{MgCl}_{2}$ (0.03 mol), $\mathrm{FeCl}_{3}(0.01 \mathrm{~mol})$, and biochar $(10.0 \mathrm{~g})$ was adjusted to about 10 with $1 \mathrm{~mol} \mathrm{~L}^{-1} \mathrm{NaOH}$ aqueous solution. The obtained slurry was aged for $3 \mathrm{~d}$ at $70{ }^{\circ} \mathrm{C}$, then filtered, and washed with DI water. Biochar/MgFe-LDH sample was then obtained by drying the filtrate at $70{ }^{\circ} \mathrm{C}$ in an oven.

\subsection{Characterizations}

Specific surface areas of the samples were measured with a Quantachrome Autosorb-1

surface area analyzer using $\mathrm{N}_{2}$ (BET) sorption methods. Thermogravimetric (TG) curves for the sorbents were determined by using a Mettler TGA/DSC thermogravimetric analyzer (TGA/ DSC 1, STARe System, METTLER TOLEDO, USA) at a heating rate of $10{ }^{\circ} \mathrm{C} / \mathrm{min}$ from $50^{\circ} \mathrm{C}$ to 
122 2.4. Batch sorption experiments

124 all the batch sorption experiments were only conducted with the modified biochar. Adsorption

125 kinetics of nitrate on the biochar/MgFe-LDH samples were examined by mixing $0.1 \mathrm{~g}$ sorbent 126 with $50 \mathrm{~mL}$ nitrate solution $(45 \mathrm{mg} / \mathrm{L}$ nitrate) in $68 \mathrm{~mL}$ digestion vessels (Environmental Express)

127 at room temperature $\left(22 \pm 0.5^{\circ} \mathrm{C}\right)$. The vessels were then shaken at $50 \mathrm{rpm}$ in a mechanical

128 shaker. At appropriate time intervals, the vessels were withdrawn and the mixtures were

129 immediately filtered through $0.22 \mu \mathrm{m}$ pore size nylon membrane filters (GE cellulose nylon

130 membrane).

131 The adsorption isotherm of nitrate on the biochar was determined similarly by mixing $0.1 \mathrm{~g}$

132 of biochar with $50 \mathrm{~mL}$ of nitrate solutions of different concentrations ranging from 0 to $88 \mathrm{mg} / \mathrm{L}$

133 in the digestion vessels. The vessels were shaken in the mechanical shaker for $24 \mathrm{~h}$ at room

134 temperature (sufficient to reach adsorption equilibrium). The samples were then withdrawn and

135 filtered through $0.22 \mu \mathrm{m}$ pore size nylon membrane filters (GE cellulose nylon membrane) to

136 determine nitrate concentrations. In addition, $\mathrm{pH}$ values of solutions before and after nitrate 
sorption were measured with a pH meter (Fisher Scientific Accumet Basic AB15).

Adsorption of $45 \mathrm{mg} / \mathrm{L}$ of nitrate solution by different adsorbent doses $(2-20 \mathrm{~g} / \mathrm{L})$ for

139 biochar/MgFe-LDH samples was also carried out using the same procedure as the adsorption

140 isotherms. The samples were shaken for $24 \mathrm{~h}$ at room temperature and then filtered. The nitrate

141 concentrations of the filtrates were measured.

142 The effects of competing compounds on nitrate sorption by the biochar/MgFe-LDH

143 composite were investigated by adding a common coexisting anion in natural water bodies

$144\left(\mathrm{SO}_{4}{ }^{2-}, \mathrm{HCO}_{3}{ }^{-1}, \mathrm{PO}_{4}{ }^{3-}\right.$, or $\left.\mathrm{NH}_{4}{ }^{+}\right)$to the $50 \mathrm{mg} / \mathrm{L}$ nitrate solutions. The concentration of each of the

145 ions added was also $50 \mathrm{mg} / \mathrm{L}$. The ratio of adsorbent to initial nitrate solution was the same as in

146 the kinetics/isotherm experiment. The vessels were shaken in the mechanical shaker for $24 \mathrm{~h}$ at

147 room temperature. The same procedures were used to determine aqueous and adsorbed nitrate

148 concentrations.

149 Nitrate was analyzed using the ultraviolet spectrophotometric screening method outlined in 150 the standard methods of examination of water and wastewater using spectrophotometry [25]. All

151 the adsorption experiments were conducted in duplicate, and the averages of the experimental

152 data were reported. Additional measurements were obtained when the duplicates had a difference

153 larger than $5 \%$.

155 3. Results and Discussion

156 3.1. Morphological structure of biochar/MgFe-LDH composite 

impregnated biochar, suggesting that the impregnation filled pores or clogged pore-openings on biochar surfaces. Thus, specific surface areas may not be considered the key parameter in determining nitrate sorption onto biochar.

The XRD pattern in the range of $10-70^{\circ}$ of the biochar/MgFe-LDH sample is shown in Fig. 1.

The pattern shows diffraction peaks of both the $\mathrm{LDH}$ structure and the $\mathrm{MgFe}_{2} \mathrm{O}_{4}$

(magnesioferrite) spinel structure (JCPDS 17-0465), which is supported by the results that some of the $\mathrm{MgFe}-\mathrm{LDH}$ microcrystals were converted into spinel ferrite when the aging temperature was higher than $40^{\circ} \mathrm{C}$ [26]. The basal spacing $\mathrm{d}$ of the biochar/MgFe-LDH sample was about $0.75 \mathrm{~nm}$, indicating that $\mathrm{MgFe}-\mathrm{LDH}$ incorporated some $\mathrm{CO}_{3}{ }^{2-}$ anions [11]. The weaker peak intensity of the spinel ferrite component compared to that of the LDH suggests that LDH is still the dominant component in the sample. Also, diffraction peaks owing to impurities were observed at $2 \theta=16.8^{\circ}, 26.7^{\circ}, 39.2^{\circ}$ and $56^{\circ}$, which corresponded to akaganeite $\left(\mathrm{Fe}^{3+} \mathrm{O}(\mathrm{OH}, \mathrm{Cl})\right.$.

This indicates that the sample was a composite of $\mathrm{MgFe}-\mathrm{LDH}$, spinel ferrite, and akaganeite.

Some patterns of quartz were also found in the XRD due to the existence of Si in wheat straw.

The specific surface area for the biochar/MgFe-LDH sample was $3.9 \mathrm{~m}^{2} \mathrm{~g}^{-1}$, which is within the range of a typical $\mathrm{LDH}$ powder with a single component, such as $\mathrm{Mg} / \mathrm{Al}-, \mathrm{Co} / \mathrm{Al}-$, and $\mathrm{Ni} / \mathrm{Al}-\mathrm{LDH}(\mathrm{Cl})$, whose specific surface areas are usually several square meters per gram [11]. Thermal decomposition showed a greater mass loss in the temperature range of about 350-500 ${ }^{\circ} \mathrm{C}$ for wheat straw biochar (WC) than for MgFe-impregnated biochar (Fig. 2). The 
mass remaining, compared to the initial mass, was $8 \%$ for wheat straw biochar and $12 \%$ for the biochar/MgFe-LDH composite, further confirming the impregnation of LDH into the biochar.

\subsection{Adsorption Kinetics}

The adsorption rate of nitrate was studied at room temperature using the initial nitrate

concentrations (45 mg/L) up to a contact time of $24 \mathrm{~h}$ (Fig.3). It appears from Fig. 3 that the

kinetics of nitrate adsorption for biochar/MgFe-LDH composite consist of two phases: an initial rapid phase with fast reactions where $74 \%$ of the adsorption is completed within $3 \mathrm{~h}$ of contact time, followed by a slow phase with an adsorption rate of about $0.086 \mathrm{mg} / \mathrm{g} / \mathrm{h}$ before reaching equilibrium. The initial high rate of nitrate uptake is probably due to the greater anion exchange ability of LDH. The slow phase is perhaps associated with the pore network and surface of the biochar which help the dispersion of LDH flakes to efficiently increase their reaction with nitrate [7]. 194 lowest standard error of estimate (SSE), and closest match of $\mathrm{q}_{\mathrm{e}}$ with the experimental results 195 (7.22 mg/g) (Table 1). Similar results were also reported by other studies [7, 12, 27, 28].

The experimental results were fitted to the kinetic models of pseudo-first-order, pseudosecond -order, and Elovich defined in Table 1. While the pseudo-first-order and Elovich model fit to the data well, the pseudo-second-order model is the most suitable one in describing the adsorption kinetics of nitrate on the biochar/MgFe-LDH composite as it had the highest $\mathrm{R}^{2}$, 


\subsection{Adsorption isotherms}

Freundlich, Langmuir and Redlich-Peterson isotherms were used to describe the adsorption characteristics of nitrate anions $[12,27,28]$. All three models described the sorption isotherm well with the Langmuir model providing a slightly higher $\mathrm{R}^{2}$ value (Table 1, Fig. 4), which is consistent with the results obtained by [7, 27, 28]. The maximum Langmuir nitrate adsorption capacity for biochar/MgFe-LDH composite was $24.8 \mathrm{mg} / \mathrm{g}$, greater than that of some previously reported activated carbon and biochar (Table 2) [5, 22, 28, 29], but lower than the $31.6 \mathrm{mg} / \mathrm{g}$ of 204 pure MgFe-LDH (3:1) reported by Sasai et al [11] and $118.11 \mathrm{mg} / \mathrm{g}$ of pure MgAl-LDH (4:1) 205 reported by Halajnia et al.[12]. According to the results of the TGA analysis, the amount of the $206 \mathrm{MgFe}-\mathrm{LDH}$ loaded onto the biochar was only about $4 \%$ of the total weight. The converted 207 maximum nitrate adsorption capacity for the pure MgFe-LDH of the composite thus should be 208 much higher $(\sim 620 \mathrm{mg} / \mathrm{g})$, conforming that biochar can distribute and stabilize ultrafine LDH 209 particles for better sorption of contaminants [7, 18].

210 Also of note was that the $\mathrm{R}^{2}$ values of all three models were very close to one another (Table

211 1), suggesting that the adsorption of nitrate on the biochar/MgFe-LDH composite may be

212 controlled by multiple processes. This is consistent with findings from previous studies of

213 phosphate sorption on LDHs, which noted that both surface adsorption and interlayer anion

214 exchange mechanisms govern the sorption processes [7, 30]. Because surface adsorption and interlayer anion exchange are both reversible processes, it is anticipated that the adsorbed nitrate on the biochar/MgFe-LDH composite desorb back into aqueous phase and become bioavailable if 


\subsection{Effect of coexisting ions}

In real systems, other ions can be present and compete with nitrate for adsorption sites.

Figure 5 shows the effects of the coexistence of phosphate, sulfate, bicarbonate, and ammonium ions on nitrate adsorption in terms of adsorption capacity at equilibrium $\left(\mathrm{q}_{\mathrm{e}}\right)$ and nitrate removal efficiency (RE). It can be seen that the influence of phosphate and sulfate on nitrate removal efficiency was very small and could be negligible. $\mathrm{Mg} / \mathrm{Fe}-\mathrm{LDH}(\mathrm{Cl})$ can incorporate nitrate anions, but not sulfate and phosphate anions, into its interlayer space via anion exchange. This is due to the ion-sieve effect produced by the spatial limits between the brucite layers [13]: the ion diameters of $\mathrm{SO}_{4}{ }^{2-}(0.46 \mathrm{~nm})$ and $\mathrm{PO}_{4}{ }^{3-}(0.476 \mathrm{~nm})$ were larger than those of $\mathrm{Cl}^{-}(0.33 \mathrm{~nm})$ or nitrate $(0.29 \mathrm{~nm})[11,32]$. Tezuka et al. [13] also reported that $\mathrm{Mg}-\mathrm{Fe}$ LDHs have relatively 231 higher selectivity for nitrate adsorption than MgAl-LDH, even in sea water with overwhelmingly 232 high levels of $\mathrm{SO}_{4}{ }^{2-}$ and $\mathrm{Cl}^{-}$. They attributed the high anion adsorption capacity but low 233 selectivity for nitrate of $\mathrm{MgAl}-\mathrm{LDH}$ to the more expansive interlayer character. Furthermore, the tunnel size of akaganeite can only let nitrate enter and replace $\mathrm{Cl}^{-}$, but not large enough for sulfate and phosphate anions [33]. This study also found that nitrate removal was greatly influenced by $\mathrm{HCO}_{3}{ }^{-}$(Fig. 5). This may be explained by the smaller ion diameter of bicarbonate 
$(0.243 \mathrm{~nm})$ [34]. If a chloride LDH is used as a starting material, the chloride can be largely replaced by bicarbonate and nitrate. Similarly with a nitrate $\mathrm{LDH}$, a certain quantity of the nitrate can be replaced by bicarbonate [35].

In general, anions of higher valence have a more significant interfering effect than monovalent anions in the oxyanion adsorption by LDH [30]. While the interfering effects of competing anions on nitrate adsorption by biochar/Mg/Fe-LDH composite follow the order of $\mathrm{HCO}_{3}{ }^{-}>\mathrm{HPO}_{4}{ }^{2-}>\mathrm{SO}_{4}{ }^{2-}$, such an unusual anion-exchange behavior cannot be explained simply by the Coulomb interaction between the anion and the anion exchange site on LDH nanosheets [11].

Besides these anions, ammonia is another important form of $\mathrm{N}$ in natural waters and can have some effect on nitrate removal. The nitrate removal efficiency of biochar/MgFe LDH composite decreased from $30.6 \%$ to $22.2 \%$ in the mixture of $\mathrm{NH}_{4}{ }^{+}$and $\mathrm{NO}_{3}{ }^{-}$(Fig.5), indicating that some absorption sites on the biochar were taken by ammonia. But the data still exhibited a high nitrate removal capacity of $8.37 \mathrm{mg} \mathrm{g}^{-1}$, suggesting that biochar/MgFe LDH composite can remove ammonia and nitrate simultaneously. Previous studies have demonstrated that, in addition to anion pollutants, LDHs can also effectively remove various positively charged compounds such as ammonia from aqueous solution and the sorption mechanisms including precipitation, surface complexation, isomorphic substitution, and chelation with anions in the interlayers of LDHs [36]. 


\subsection{Effect of adsorbents dosages}

Applying an optimum dosage of suitable adsorbent for adsorbate removal in a batch adsorption system is crucial for its cost-effective application. Fig. 6 shows the removal of nitrate as a function of adsorbent dosage in the $50 \mathrm{mg} / \mathrm{L}$ nitrate solution. In general, an increase in adsorbent dosage increased the percent removal of nitrate, likely due to the increase in adsorbent surface area and the total amount of active adsorption sites $[37,38]$. When the sorbent dosage increased from $2 \mathrm{~g} / \mathrm{L}$ to $5 \mathrm{~g} / \mathrm{L}$, the removal efficiency of nitrate increased linearly from $19.1 \%$ to $43.6 \%$ and the adsorption capacity remained at about the same level. After that, the nitrate removal efficiency increased with increasing dosage to $80.2 \%$, but the adsorption capacity decreased from $3.88 \mathrm{mg} / \mathrm{g}$ to $1.84 \mathrm{mg} / \mathrm{g}$. This indicates that the optimum dosage for nitrate removal should be between 5-10 g/L. The adsorption capacities of the adsorbent $(Q \mathrm{e})$ were higher at lower adsorbent loadings, which may be attributed to the fact that, at higher adsorbent loadings, some of the adsorption sites remain unsaturated during the adsorption process [39].

\section{Conclusions}

Nitrate adsorption properties of biochar/MgFe-LDH composite prepared by liquid-phase deposition were examined in this study. XRD analysis demonstrated that LDH particles were successfully deposited onto the carbon surface within the biochar matrix. The obtained biochar/MgFe-LDH composite showed a strong sorption ability to nitrate in aqueous solutions with the maximum uptake capacity at $24.8 \mathrm{mg} / \mathrm{g}$, which is higher than most of the unmodified 
activated carbon (AC)/biochar adsorbents. Furthermore, the biochar/MgFe-LDH composite

showed a high selectivity for nitrate due to its suitable interlayer spacing for fixing $\mathrm{NO}_{3}{ }^{-}$ion, irrespective of the existence of sulfate and phosphate. The increase of adsorbent dosage

increased the percent removal of nitrate while the adsorption capacity decreased, making 5-10 $\mathrm{g} / \mathrm{L}$ the optimum dosage for nitrate removal. Because biochar is a low-cost material commonly

282 derived from waste biomass, using biochar as a support to distribute and stabilize LDH creates

283 an environmentally friendly adsorbent. Findings from this work demonstrated potential

284 applications of biochar/MgFe-LDH composite as a green absorbent for nitrate removal from

285 water and as a soil amendment for reduction of soil nitrate leaching.

\section{Acknowledgments}

288 This research was partially supported by the NSF through Grant CBET-1054405, the Jiangsu 289 Agriculture Science and Technology Innovation Fund (CX(13)3039), and the Special Fund for 290 Agro-scientific Research in the Public Interest (201503106). 
295 Eng-asce, 123 (1997) 371-380.

[1] E.V.S.P.P. Rao, K., Strategies for combating nitrate pollution, Curr Sci India, 91 (2006) 5.

[2] A. Kapoor, T. Viraraghavan, Nitrate removal from drinking water - Review, J Environ

[3] A. Bhatnagar, M. Sillanpää, A review of emerging adsorbents for nitrate removal from water,

Chem Eng J, 168 (2011) 493-504.

[4] D. Mohan, A. Sarswat, Y.S. Ok, C.U. Pittman Jr, Organic and inorganic contaminants removal from water with biochar, a renewable, low cost and sustainable adsorbent - A critical review, Bioresource Technol, 160 (2014) 191-202.

[5] K. Mizuta, T. Matsumoto, Y. Hatate, K. Nishihara, T. Nakanishi, Removal of nitrate-nitrogen from drinking water using bamboo powder charcoal, Bioresource Technol, 95 (2004) 255-257.

[6] Y. Yao, B. Gao, M. Inyang, A.R. Zimmerman, X.D. Cao, P. Pullammanappallil, L.Y. Yang, Removal of phosphate from aqueous solution by biochar derived from anaerobically digested sugar beet tailings, J Hazard Mater, 190 (2011) 501-507.

[7] M. Zhang, B. Gao, Y. Yao, M.D. Inyang, Phosphate removal ability of biochar/MgAl-LDH ultra-fine composites prepared by liquid-phase deposition, Chemosphere, 92 (2013) 1042-1047. [8] Y. Yao, B. Gao, M. Inyang, A.R. Zimmerman, X. Cao, P. Pullammanappallil, L. Yang, Biochar derived from anaerobically digested sugar beet tailings: Characterization and phosphate removal potential, Bioresource Technol, 102 (2011) 6273-6278.

[9] Y. Yao, B. Gao, J.J. Chen, M. Zhang, M. Inyang, Y.C. Li, A. Alva, L.Y. Yang, Engineered 
carbon (biochar) prepared by direct pyrolysis of $\mathrm{Mg}$-accumulated tomato tissues:

Characterization and phosphate removal potential, Bioresource Technol, 138 (2013) 8-13.

[10] S. Tezuka, R. Chitrakar, A. Sonoda, K. Ooi, T. Tomida, Studies on Selective Adsorbents for

315 Oxo-Anions. NO3 - Adsorptive Properties of Ni-Fe Layered Double Hydroxide in Seawater, 316 Adsorption, 11 (2005) 751-755.

317 [11] R. Sasai, W. Norimatsu, Y. Matsumoto, Nitrate-ion-selective exchange ability of layered 318 double hydroxide consisting of MgII and FeIII, J Hazard Mater, 215-216 (2012) 311-314.

319 [12] A. Halajnia, S. Oustan, N. Najafi, A.R. Khataee, A. Lakzian, Adsorption-desorption

320 characteristics of nitrate, phosphate and sulfate on $\mathrm{Mg}-\mathrm{Al}$ layered double hydroxide, Appl Clay

321 Sci, 80-81 (2013) 305-312.

322 [13] S. Tezuka, R. Chitrakar, A. Sonoda, K. Ooi, T. Tomida, Studies on selective adsorbents for 323 oxo-anions. Nitrate ion-exchange properties of layered double hydroxides with different metal 324 atoms, Green Chem, 6 (2004) 104-109.

325 [14] L. Torres-Dorante, J. Lammel, H. Kuhlmann, Use of a layered double hydroxide (LDH) to 326 buffer nitrate in soil: long-term nitrate exchange properties under cropping and fallow conditions, 327 Plant Soil, 315 (2009) 257-272.

328 [15] B.A. P Nalawade, V J kadam and R S Hirlekar, Layered double hydroxides: A review, J Sci 329 Ind Res India, 68 (2009) 6.

[16] X.-L. Wu, L. Wang, C.-L. Chen, A.-W. Xu, X.-K. Wang, Water-dispersible magnetite-graphene-LDH composites for efficient arsenate removal, J Mater Chem, 21 (2011) 
8333 [17] F. Bruna, R. Celis, M. Real, J. Cornejo, Organo/LDH nanocomposite as an adsorbent of

336 [18] M. Zhang, B. Gao, J. Fang, A.E. Creamer, J.L. Ullman, Self-assembly of needle-like layered 337 double hydroxide (LDH) nanocrystals on hydrochar: characterization and phosphate removal 338 ability, RSC Advances, 4 (2014) 28171-28175.

339 [19] A.U. Rajapaksha, S.S. Chen, D.C.W. Tsang, M. Zhang, M. Vithanage, S. Mandal, B. Gao, 340 N.S. Bolan, Y.S. Ok, Engineered/designer biochar for contaminant removal/immobilization from 341 soil and water: Potential and implication of biochar modification, Chemosphere, 148 (2016) $342 \quad 276-291$

343 [20] M. Inyang, B. Gao, Y. Yao, Y. Xue, A. Zimmerman, A. Mosa, P. Pullammanappallil, Y. Ok, 344 X. Cao, A review of biochar as a low-cost adsorbent for aqueous heavy metal removal, Crit Rev 345 Env Sci Tec, doi: 10.1080/10643389.2015.1096880 (2016).

346 [21] M. Zhang, B. Gao, Y. Yao, Y.W. Xue, M. Inyang, Synthesis of porous MgO-biochar 347 nanocomposites for removal of phosphate and nitrate from aqueous solutions, Chem Eng J, 210 348 (2012) 26-32.

349 [22] Y. Yao, B. Gao, M. Zhang, M. Inyang, A.R. Zimmerman, Effect of biochar amendment on 351 (2012) 1467-1471. 
[23] Y. Yao, B. Gao, J. Fang, M. Zhang, H. Chen, Y. Zhou, A. Creamer, Y. Sun, L. Yang,

Characterization and environmental applications of clay-biochar composites, Chem Eng J, 242 (2014) 136-143.

[24] Y. Sun, B. Gao, Y. Yao, J. Fang, M. Zhang, Y. Zhou, H. Chen, L. Yang, Effects of feedstock type, production method, and pyrolysis temperature on biochar and hydrochar 357 properties, Chem Eng J, 240 (2014) 574-578.

358 [25] A.W.W.A. American Public Health Association, Water Environment Federation, Standard 359 methods for the examination of water and wastewater, $22^{\text {nd }}$ edition, American Public Health 360 Association, American Water Works Association, Water Environment Federation, Washington, 361 D.C., 2012.

362 [26] Q. Xu, Y. Wei, Y. Liu, X. Ji, L. Yang, M. Gu, Preparation of Mg/Fe spinel ferrite 363 nanoparticles from $\mathrm{Mg} / \mathrm{Fe}-\mathrm{LDH}$ microcrystallites under mild conditions, Solid State Sci, 11 364 (2009) 472-478.

365 [27] A. Bhatnagar, E. Kumar, M. Sillanpää, Nitrate removal from water by nano-alumina:

366 Characterization and sorption studies, Chem Eng J, 163 (2010) 317-323.

367 [28] H. Demiral, G. Gündüzoğlu, Removal of nitrate from aqueous solutions by activated carbon 368 prepared from sugar beet bagasse, Bioresource Technol, 101 (2010) 1675-1680.

369 [29] P.C. Mishra, R.K. Patel, Use of agricultural waste for the removal of nitrate-nitrogen from 371 [30] K.-H. Goh, T.-T. Lim, Z. Dong, Application of layered double hydroxides for removal of 
oxyanions: A review, Water Res, 42 (2008) 1343-1368.

[31] U. Schwertmann, J. Friedl, G. Pfab, A New Iron(III) Oxyhydroxynitrate, J Solid State Chem, 126 (1996) 336.

[32] W.H. Bannister, The biological chemistry of the elements: The inorganic chemistry of life:

By J J R Fraústo da Silva and R J P Williams. pp 561. Clarendon Press, Oxford. 1991. ISBN

377 0-19-855598-9, Biochem Educ, 20 (1992) 62-63.

378 [33] A. Fernandez-Martinez, V. Timon, G. Roman-Ross, G.J. Cuello, J.E. Daniels, C. Ayora, 379 The structure of schwertmannite, a nanocrystalline iron oxyhydroxysulfate, Am Mineral, 95 $380 \quad$ (2010) 1312-1322.

381 [34] J. LaRusch, J. Jung, I.J. General, M.D. Lewis, H.W. Park, R.E. Brand, A. Gelrud, M.A. 382 Anderson, P.A. Banks, D. Conwell, C. Lawrence, J. Romagnuolo, J. Baillie, S. Alkaade, G. Cote, 383 T.B. Gardner, S.T. Amann, A. Slivka, B. Sandhu, A. Aloe, M.L. Kienholz, D. Yadav, M.M. 384 Barmada, I. Bahar, M.G. Lee, D.C. Whitcomb, G. the North American Pancreatitis Study, 385 Mechanisms of CFTR Functional Variants That Impair Regulated Bicarbonate Permeation and 386 Increase Risk for Pancreatitis but Not for Cystic Fibrosis, PLoS Genetics, 10 (2014) e1004376. 387 [35] L.T.-D. Witzke T. , F. Bullerjahn, and H. Pollmann, Use of Layered Double Hydroxides 388 (LDH) of the Hydrotalcite Group as Reservoir Minerals for Nitrate in Soils - Examination of the 389 Chemical and Mechanical Stability, in: S.V. Krivovichev (Ed.) Minerals as Advanced Materials 391 [36] X.F. Liang, Y.B. Zang, Y.M. Xu, X. Tan, W.G. Hou, L. Wang, Y.B. Sun, Sorption of metal 
2

3

4

5

7 cations on layered double hydroxides, Colloid Surface A, 433 (2013) 122-131.

[37] N. Öztürk, T.E.l. Bektaş, Nitrate removal from aqueous solution by adsorption onto various materials, J Hazard Mater, 112 (2004) 155-162.

[38] X. Chen, G. Chen, L. Chen, Y. Chen, J. Lehmann, M.B. McBride, A.G. Hay, Adsorption of copper and zinc by biochars produced from pyrolysis of hardwood and corn straw in aqueous 397 solution, Bioresource Technol, 102 (2011) 8877-8884.

398 [39] S. Hamoudi, R. Saad, K. Belkacemi, Adsorptive Removal of Phosphate and Nitrate Anions 399 from Aqueous Solutions Using Ammonium-Functionalized Mesoporous Silica, Ind Eng Chem $400 \quad$ Res, 46 (2007) 8806-8812. 
Table 1. Summary of kinetic and isotherm models and their best-fit parameters for the adsorption of nitrate onto the biochar/MgFe-LDH composite

\begin{tabular}{|c|c|c|c|c|c|c|}
\hline \multirow[b]{2}{*}{ Parameters } & \multirow[b]{2}{*}{$\begin{array}{l}\text { First-order: } \\
q_{t}=q_{e}\left(1-e^{-k t}\right)\end{array}$} & \multirow{2}{*}{$\begin{array}{l}\text { Kinetic Models } \\
\text { Second-order: } \\
q_{t}=\frac{k q_{e}^{2} t}{1+k q_{e} t}\end{array}$} & \multirow[b]{2}{*}{$\begin{array}{l}\text { Elovich: } \\
q_{t}=\frac{1}{\beta} \ln (\beta o t+1)\end{array}$} & \multirow[b]{2}{*}{$\begin{array}{l}\text { Langmuir: } \\
q_{e}=\frac{q_{\operatorname{mx}} K C_{e}}{1+K C_{e}}\end{array}$} & \multicolumn{2}{|c|}{ Isotherm Models } \\
\hline & & & & & $\begin{array}{l}\text { Freundlich: } \\
q_{e}=K_{f} C_{e}^{n}\end{array}$ & $\begin{array}{l}\text { Redlich-Peterson: } \\
q_{e}=\frac{q_{\max } K C_{e}}{1+K C_{e}^{n}}\end{array}$ \\
\hline Parameter 1 & $\mathrm{k}=0.607$ & $\mathrm{k}=0.109$ & $\alpha=17.357$ & $\mathrm{~K}=0.012$ & $\mathrm{~K}=0.55$ & $\mathrm{~K}=0.0133$ \\
\hline Parameter 2 & $\mathrm{q}_{\mathrm{e}}=6.6$ & $\mathrm{q}_{\mathrm{e}}=7.4$ & $\beta=0.767$ & $\mathrm{q}_{\max }=24.8$ & $\mathrm{n}=0.718$ & $\mathrm{q}_{\max }=22.72$ \\
\hline Parameter 3 & - & - & - & - & - & $\mathrm{n}=0.983$ \\
\hline $\mathrm{R}^{2}$ & 0.960 & 0.986 & 0.938 & 0.977 & 0.969 & 0.977 \\
\hline SEE & 0.986 & 0.334 & 1.532 & 1.585 & 2.15 & 1.591 \\
\hline
\end{tabular}


Table 2. Comparison of the Langmuir maximum nitrate sorption capacity of various sorbents (LDH and unmodified AC/biochar)

\begin{tabular}{|c|c|c|c|}
\hline sorbents & $\begin{array}{l}\text { Max. sorption } \\
\text { capacities }(\mathrm{mg} / \mathrm{g})\end{array}$ & Experiment condition & references \\
\hline Mg-Al LDH(4:1) & 118.11 & $\begin{array}{l}20^{\circ} \mathrm{C}, 5 \mathrm{~g} / \mathrm{L} \text { absorbents, } \\
0.02-5 \mathrm{mmol} \mathrm{L}{ }^{-1} \text { nitrate }\end{array}$ & [12] \\
\hline $\mathrm{Mg}-\mathrm{Fe} \operatorname{LDH}(3: 1)$ & 31.6 & $\begin{array}{l}26.85^{\circ} \mathrm{C}, 2 \mathrm{~g} / \mathrm{L} \text { absorbents, } \\
0.01 \mathrm{~mol} \mathrm{~L}^{-1} \text { nitrate }\end{array}$ & [11] \\
\hline Ni-Fe LDH & 20.46 & $\begin{array}{l}\text { room temperature, } 1 \mathrm{~g} / \mathrm{L} \\
\text { absorbents, } 0.1 \mathrm{~mol} \mathrm{~L}^{-1} \text { nitrate, } \\
\text { Seawater }\end{array}$ & [10] \\
\hline $\mathrm{Mg}-\mathrm{Fe} \mathrm{LDH}$ & 5.022 & $\begin{array}{l}\text { room temperature, } 1 \mathrm{~g} / \mathrm{L} \\
\text { absorbents, } 0.1 \mathrm{~mol} \mathrm{~L}^{-1} \text { nitrate }\end{array}$ & [13] \\
\hline $\begin{array}{l}\text { Activated carbon } \\
\text { from sugar beet } \\
\text { bagasse }\end{array}$ & 9.14 & $\begin{array}{l}25^{\circ} \mathrm{C}, 2 \mathrm{~g} / \mathrm{L} \text { absorbents, } \\
10-200 \mathrm{mg} / \mathrm{L} \text { nitrate }\end{array}$ & {$[28]$} \\
\hline $\begin{array}{l}\text { Charcoal of wheat } \\
\text { straw (WSC) and } \\
\text { mustard } \\
\text { straw(MSC),commerc } \\
\text { ial activated } \\
\text { charcoal(CAC) }\end{array}$ & $\begin{array}{l}4.87 \text { (WSC), } \\
5.40 \text { (MSC), } \\
5.76 \text { (CAC) }\end{array}$ & $\begin{array}{l}15^{\circ} \mathrm{C}, 8-80 \mathrm{~g} / \mathrm{L} \text { absorbents, } \\
0-105 \mathrm{mg} / \mathrm{L} \text { nitrate }\end{array}$ & [29] \\
\hline $\begin{array}{l}\text { Activated Bamboo } \\
\text { charcoal(BPC) and } \\
\text { CAC }\end{array}$ & $\begin{array}{l}5.54(\mathrm{BPC}) \\
4.83(\mathrm{CAC})\end{array}$ & $\begin{array}{l}10^{\circ} \mathrm{C}, 1.25 \mathrm{~g} / \mathrm{L} \text { absorbents, } \\
0-45 \mathrm{mg} / \mathrm{L} \text { nitrate }\end{array}$ & {$[5]$} \\
\hline $\begin{array}{l}\text { Sugarcane bagasse } \\
\text { biochar at } 600^{\circ} \mathrm{C}\end{array}$ & 0.64 & $\begin{array}{l}22^{\circ} \mathrm{C}, 2 \mathrm{~g} / \mathrm{L} \text { absorbents, } \\
34 \mathrm{mg} / \mathrm{L} \text { nitrate, }\end{array}$ & [22] \\
\hline MgFe-LDH biochar & 24.8 & $\begin{array}{l}\text { room temperature, } 2 \mathrm{~g} / \mathrm{L} \\
\text { absorbents, } 0-88 \mathrm{mg} / \mathrm{L} \text { nitrate }\end{array}$ & This study \\
\hline
\end{tabular}




\section{Figure Captions}

Fig. 1 XRD patterns of the biochar/ MgFe LDH composite

Fig. 2 TGA curves for the wheat straw biochar (WC) and biochar/MgFe-LDH composite

$(\mathrm{MgFe}-\mathrm{LDH} / \mathrm{WC})$

Fig. 3 Adsorption kinetic data and modeling for nitrate onto the biochar/MgFe-LDH composite

( $2 \mathrm{~g} / \mathrm{L}$ absorbents and $45 \mathrm{mg} / \mathrm{L}$ nitrate)

Fig. 4 Adsorption isotherm for nitrate onto the biochar/MgFe-LDH composite ( $2 \mathrm{~g} / \mathrm{L}$ absorbents and $0-68 \mathrm{mg} / \mathrm{L}$ nitrate)

Fig. 5 Effect of coexisting ions on nitrate removal by the biochar/MgFe-LDH composite (2 g/L absorbents, the ion concentration were all $50 \mathrm{mg} / \mathrm{L}$ )

Fig. 6 Effect of adsorbent dosage on removal efficiency and adsorption capacity of nitrate by the biochar/MgFe-LDH composite (45 mg/L nitrate) 
Fig. 1

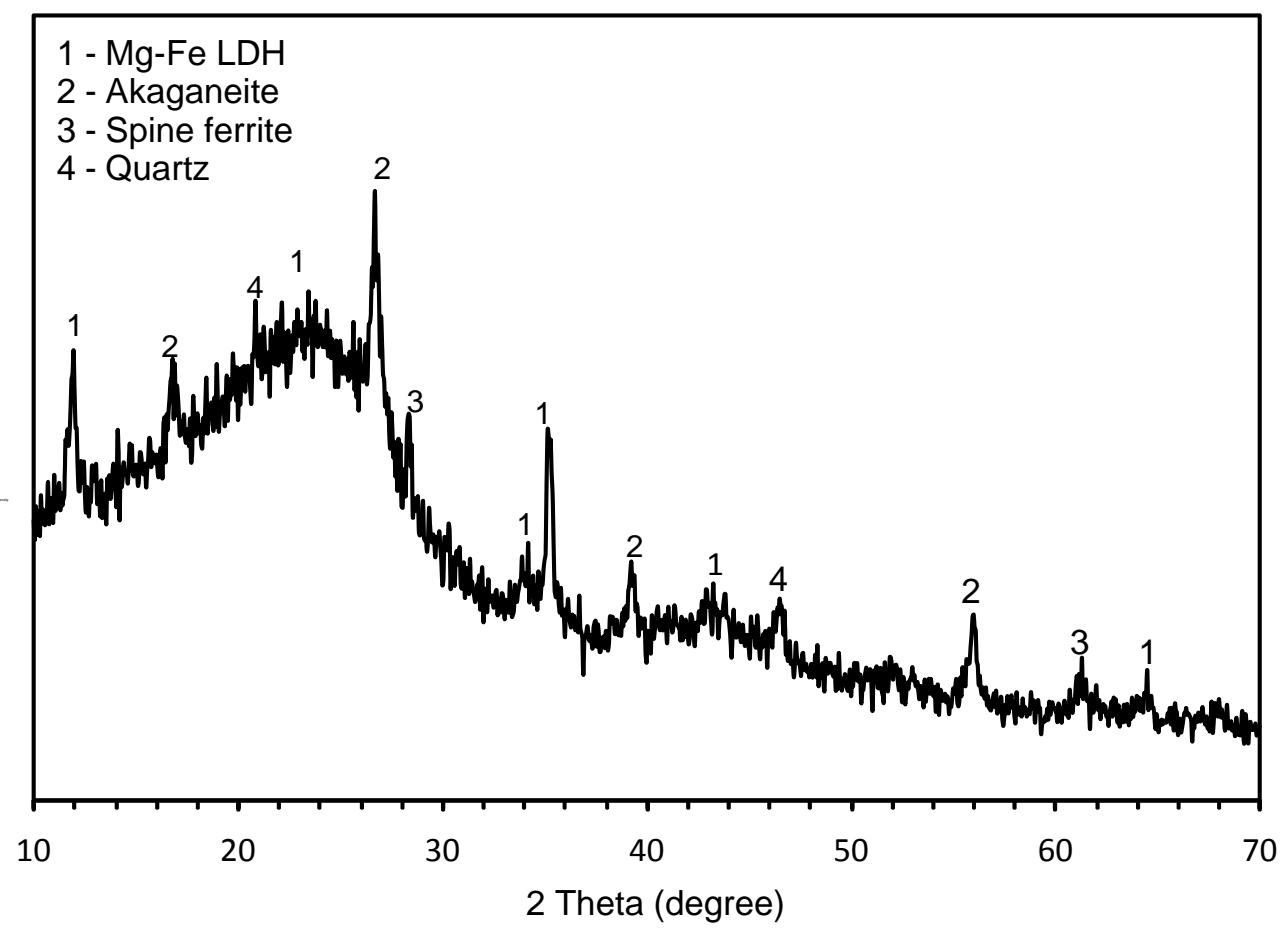


Fig. 2

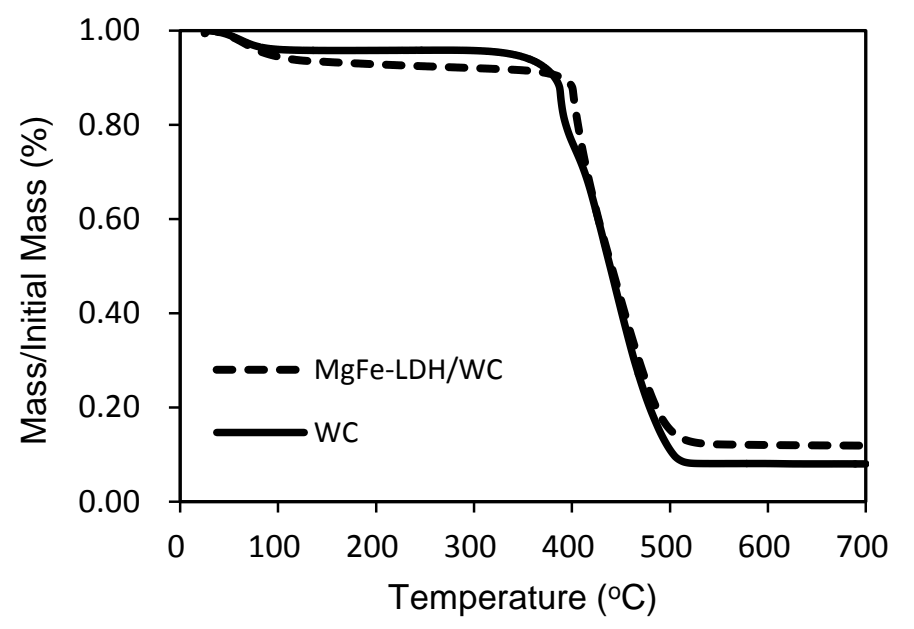


Fig. 3

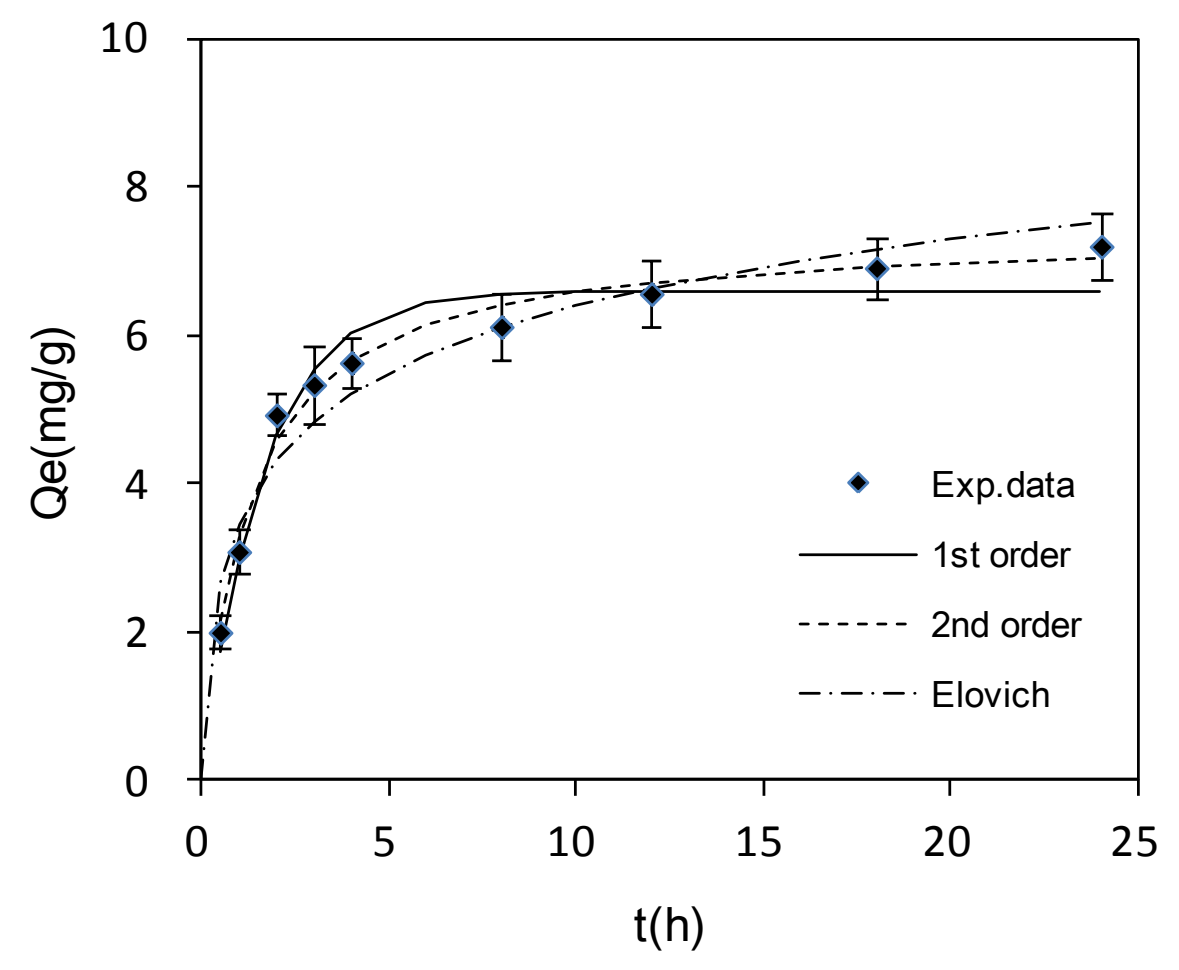


Fig. 4

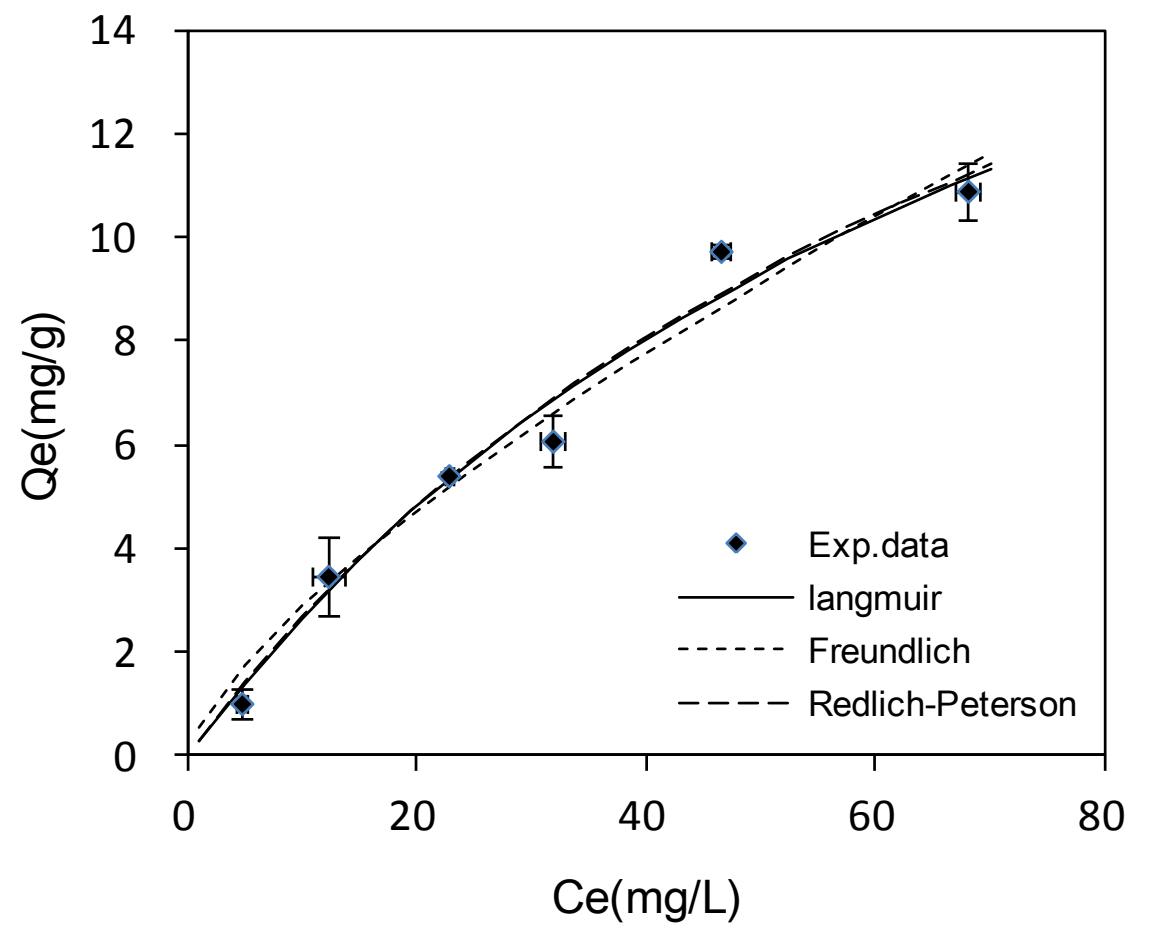

33

34

35

36

37

38

39

40

41

42

43

44

45

46

47

48

49

50

51

52

53

54

55

56

57

58

59

60

61

62

63

64

65 
Fig. 5

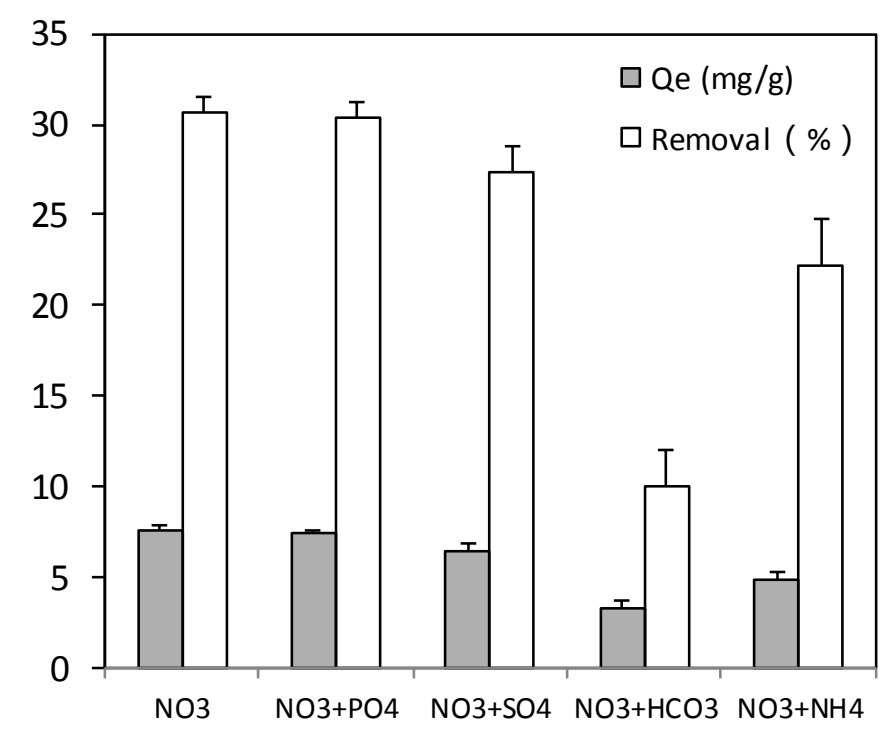

28

29

30

31

32

33

34

35

36

37

38

39

40

41

42

43

44

45

46

47

48

49

50

51

52

53

54

55

56

57

58

59

60

61

62

63

64

65 
Fig. 6

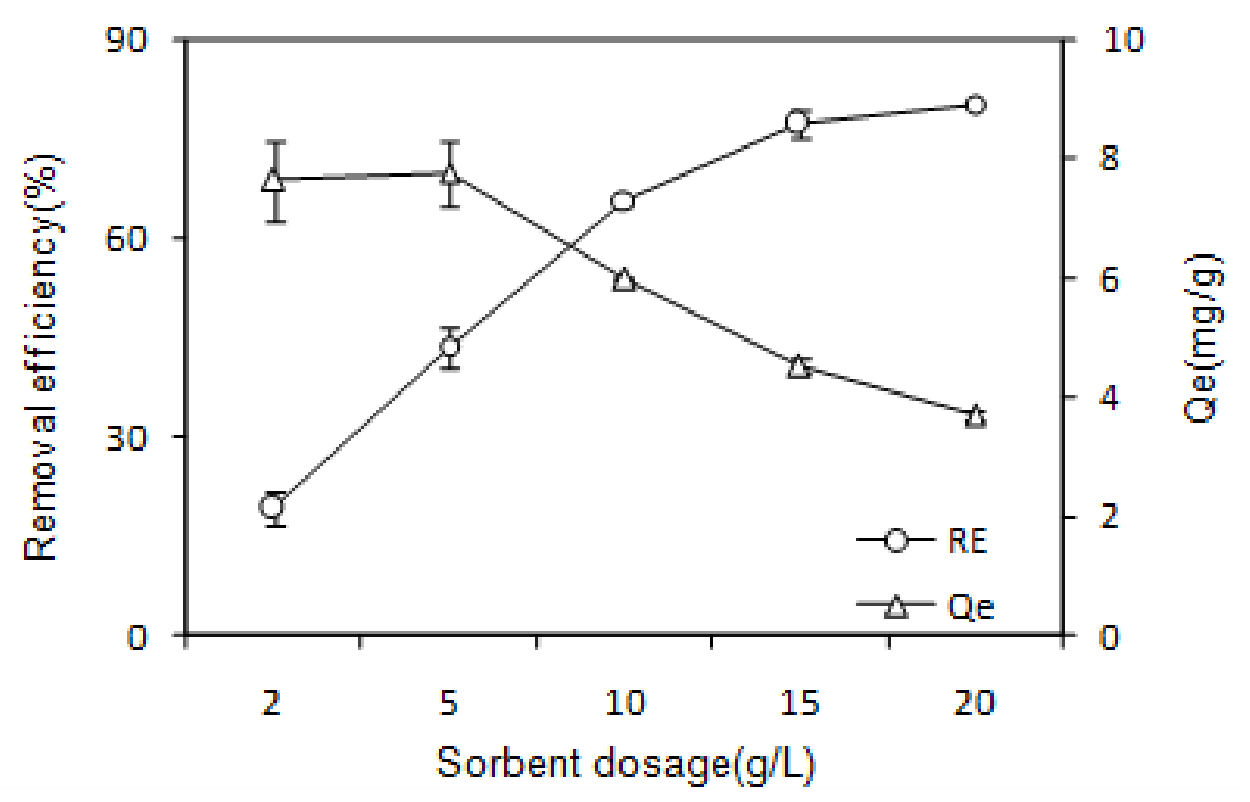



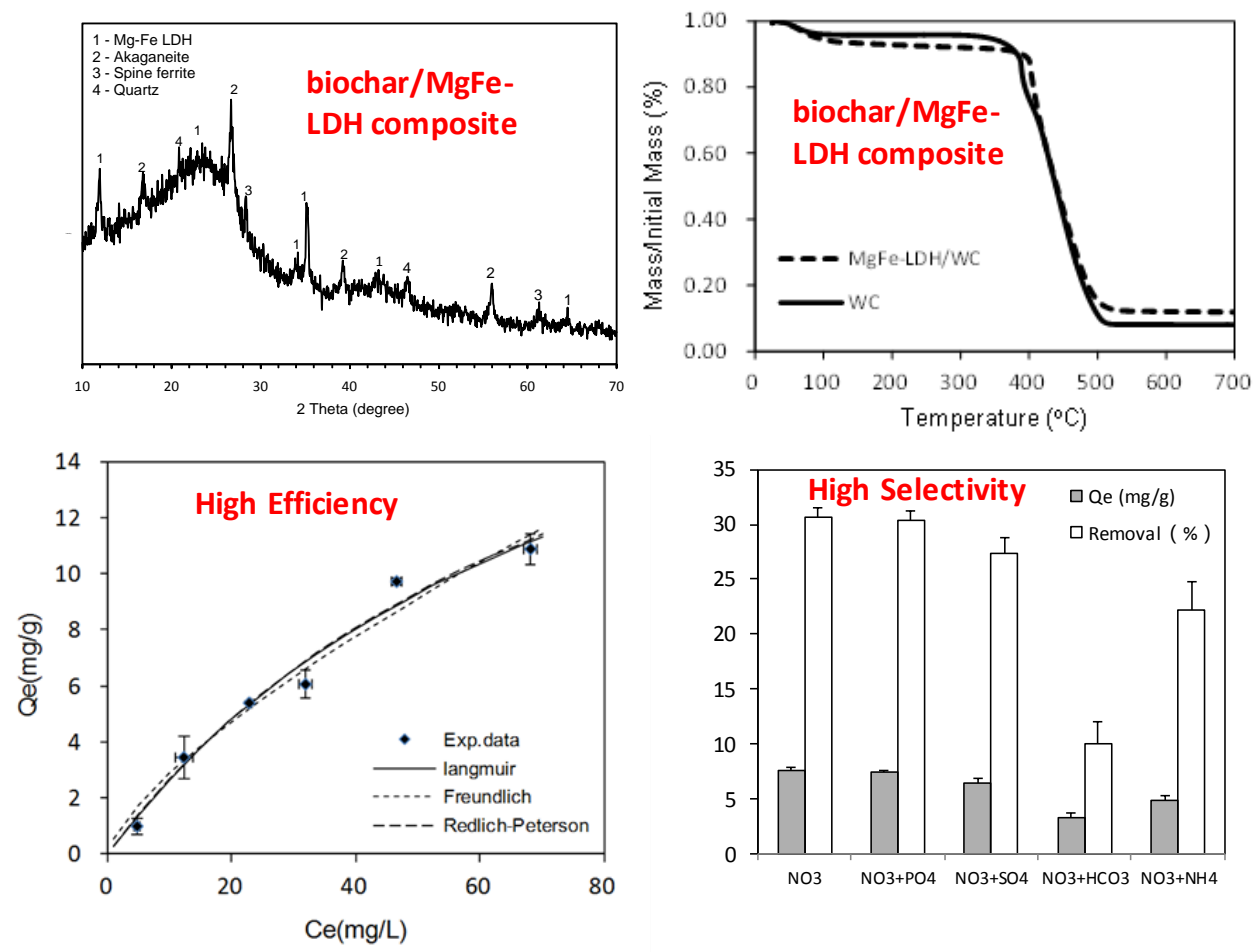